\title{
Analisis Kausalitas Pemahaman Konsep Dengan Kemampuan Berpikir Kreatif Siswa Pada Pemecahan Masalah Fisika
}

\author{
Mochammad Maulana Trianggono \\ IKIP PGRI Jember \\ Email: maulanafisika09@gmail.com
}

Received January 17, 2017; Revised March 20, 2017; Accepted March 29, 2017

\begin{abstract}
Abstrak
Kemampuan berpikir tingkat tinggi memiliki peranan penting dalam membentuk karakter kreatif dan kritis seseorang dalam menyelesaikan permasalahan fisika. Kemampuan berpikir tingkat tinggi pada umumnya didukung oleh kualitas pemahaman konsep seseorang, dalam artian kualitas pemahaman seseorang terhadap suatu konsep sinergi dengan kualitas kemampuan berpikir tingkat tingginya. Tujuan penelitian ini adalah untuk mendeskripsikan hubungan kausalitas antara pemahaman konsep dengan kemampuan berpikir kreatif siswa dalam pemecahan masalah fisika berdasarkan data penelitian yang telah dilakukan di kelas X IPA 2 SMAN 4 Jember. Data pemahaman konsep dan kemampuan berpikir kreatif diperoleh melalui pre-test dan post-test menggunakan tes objektif dan uraian. Data hasil penelitian tersebut dianalisis menggunakan analisis regresi linier dan dijelaskan secara deskriptif berdasarkan $n$-gain pada masing-masing indikator pemahaman konsep dan kemampuan berpikir kreatif. Kajian tentang hubungan kausalitas antara pemahaman konsep dan kemampuan berpikir kreatif menunjukkan bahwa keduanya memiliki pengaruh yang saling konstruktif dalam menghasilkan penyelesaian yang komprehensif dari suatu permasalahan fisika.
\end{abstract}

Kata Kunci: Pemahaman Konsep, Kemampuan Berpikir Kreatif, Pemecahan Masalah Fisika

\section{Casualty Analysis Of Concept Understanding With Creative Thinking Abilities Of Student In Physics Problem Solving}

\begin{abstract}
High order thinking skills have an important role in shaping the creative and critical character in physics problem-solving. High order thinking skills are generally supported by the quality of concept understanding, it means that the quality of concept understanding is synergy with the quality of high order thinking skills. The aim of this study is to describe the causal relationship between the concept understanding with creative thinking abilities of students in physics problems solving based on research data in class X IPA 2 - SMAN 4 Jember. Data of concept understanding and creative thinking abilities are obtained from pre-test and post-test using objective and essay test. Research data is analyzed by linear regression analysis and descriptive method based on n-gain of each indicator of concept understanding and creative thinking abilities. Studies on the causal relationship between the understanding of the concept and creative thinking abilities indicate that both have mutual constructive proportions in generating a comprehensive solution of a physics problem.
\end{abstract}

Keyword: Concept Understanding, Creative Thinking Abilities, Physics Problem Solving

\section{PENDAHULUAN}

Perkembangan ilmu pendidikan di Indonesia saat ini sudah mengarah pada kemampuan berpikir tingkat tinggi atau sering disebut sebagai High Order Thinking Skill (HOTS). Standar pendidikan di Indonesia semakin lama akan semakin meningkat. Peningkatan tersebut dipengaruhi oleh perkembangan pola pikir global yang berupaya menghasilkan manusia yang profesional dan mampu menyelesaikan suatu permasalahan dengan cepat, ringkas, dan tepat sasaran. Persaingan bebas yang terjadi secara global menyebabkan persaingan antar profesional-profesional dari seluruh dunia menjadi terbuka. Manusia yang kurang unggul dari manusia lainnya dari seluruh dunia akan tergusur posisinya. Tantangan global ini yang menjadi stimulus perkembangan pendidikan di 
Indonesia menjadi berorientasi kepada berpikir tingkat tinggi.

Kemampuan berpikir tingkat tinggi pada dasarnya dibagi menjadi kemampuan berpikir kritis, berpikir kreatif, dan metakognitif. Masing-masing kemampuan tersebut memiliki karakteristik yang berbeda-beda. Menurut Ennis (1995), berpikir kritis merupakan proses berpikir yang melibatkan alasan-alasan logis dan reflektif dalam menentukan keputusan. Berdasarkan deskripsi tersebut, kemampuan berpikir kritis memiliki karakteristik logis, beralasan, reflektif, dan berpikir mendalam tentang suatu hal.

Kemampuan berpikir kreatif memiliki karakteristik divergen. Karakteristik divergen yang dimaksud adalah kemampuan berpikir secara terbuka. Johnson (2010) menjelaskan bahwa berpikir kreatif adalah sebuah kebiasaan dari pikiran yang dilatih dengan memperhatikan intuisi, menghidupkan imajinasi, mengungkapkan kemungkinankemungkinan baru, membuka sudut pandang yang menakjubkan, dan membangkitkan ideide yang tidak terduga. Pendapat lain diungkapkan oleh McGregor (2007), yang menjelaskan bahwa berpikir kreatif adalah salah satu jenis berpikir yang mengarah pada pemerolehan wawasan baru, pendekatan baru, perspektif baru, atau cara baru dalam memahami sesuatu. Berdasarkan deskripsi tersebut dapat dikatakan bahwa kemampuan berpikir kreatif adalah kemampuan seseorang dalam berpikir dengan sudut pandang yang berbeda-beda dan menghidupkan imajinasinya untuk menghasilkan ide-ide baru yang digunakan untuk menyelesaikan suatu permasalahan.

Permasalahan yang ada dalam ilmu fisika terkait dengan permasalahan tentang alam dan gejalanya. Gejala alam yang menjadi objek kajian fisika terdiri atas kompleksitas hubungan antar peristiwa yang pada akhirnya menjadi suatu fakta, teori, konsep, prinsip, dan hukum-hukum fisika. Permasalahan yang ada dalam ilmu fisika dapat diselesaikan jika seseorang mampu memahami konsep dasar fisika. Arends (2012) menjelaskan bahwa konsep menjadi fondasi bagi jaringan ide yang menuntun pemikiran seseorang. Pemahaman terhadap suatu konsep fisika sangat dibutuhkan dalam proses pemecahan masalah fisika. Pemahaman konsep dalam taksonomi Bloom merupakan kemampuan kognitif tingkat 2 (C2). Pemahaman konsep siswa yang rendah akan menyebabkan siswa tersebut kesulitan dalam mencapai kemampuan kognitif pada tingkat yang lebih tinggi. Permasalahan fisika berisi tentang kompleksitas hubungan antar konsep, sehingga diperlukan pemahaman konsep yang baik dalam pemecahan masalah fisika. Sebagai contoh permasalahan fisika dalam kehidupan sehari-hari; mengapa terdapat rembesan air di permukaan luar gelas berisi air dingin/ air es? Permasalahan tersebut dapat dijawab jika siswa paham tentang konsep perpindahan kalor dan perubahan wujud zat.

Pentingnya pemahaman konsep dan kemampuan berpikir kreatif dalam pemecahan masalah fisika layak untuk dikaji baik dari segi peran masing-masing variabel, maupun juga dari segi hubungan kausalitas keduanya dalam proses pemecahan masalah fisika. Pemahaman konsep dan kemampuan berpikir kreatif memiliki hubungan sinergi yang saling memperkuat. Wulandari (2016) menemukan bahwa kontribusi kemampuan berpikir kreatif terhadap pemahaman konsep sebesar $29,16 \%$ yang berarti bahwa semakin tinggi nilai kemampuan berpikir kreatif maka semakin tinggi pula pemahaman konsep. Susanto (2011) mengatakan bahwa pemahaman terhadap suatu konsep dalam pemecahan masalah akan dapat menimbulkan pola pikir kreatif pada siswa. Pola pikir kreatif akan menstimulus kemampuan berpikir kreatif siswa lebih berkembang. Siswa yang memiliki kemampuan berpikir kreatif yang tinggi akan lebih mudah menerima konsep baru yang diberikan oleh guru. Siswa dengan kemampuan berpikir kreatif memiliki cara-cara kreatif dalam memahami suatu konsep.

Anderson dan Krathwohl (2001) berpendapat bahwa siswa dikatakan sudah memahami suatu konsep jika dapat mengkonstruksi makna dari pesan-pesan pembelajaran, baik yang bersifat lisan, tulisan ataupun grafis, yang disampaikan melalui pengajaran, buku, atau layar komputer. Siswa memahami ketika menghubungkan pengetahuan baru dan

\section{2 | Trianggono, Analisis Kausalitas Pemahaman Konsep Dengan Kemampuan ...}


lama atau pengetahuan baru yang masuk dipadukan dengan skema-skema dan kerangka-kerangka kognitif yang telah ada. Pada taksonomi Bloom yang telah direvisi diberikan tujuh indikator pemahaman konsep, meliputi; Interpreting, Exemplifying, Classifying, Summarizing, Inferring, Comparing, Explaining. Indikator pemahaman konsep tersebut nantinya akan dikaji keterkaitannya dengan kemampuan berpikir kreatif.

Guilford (1967) menjelaskan bahwa kemampuan berpikir kreatif berhubungan dengan konsep berpikir divergen yang memiliki karakteristik kelancaran (fluency), kelenturan (flexibility), keaslian (originality), dan elaborasi (elaboration). Karakteristik tersebut kemudian menjadi indikator dari kemampuan berpikir kreatif, yakni kemampuan berpikir lancar;

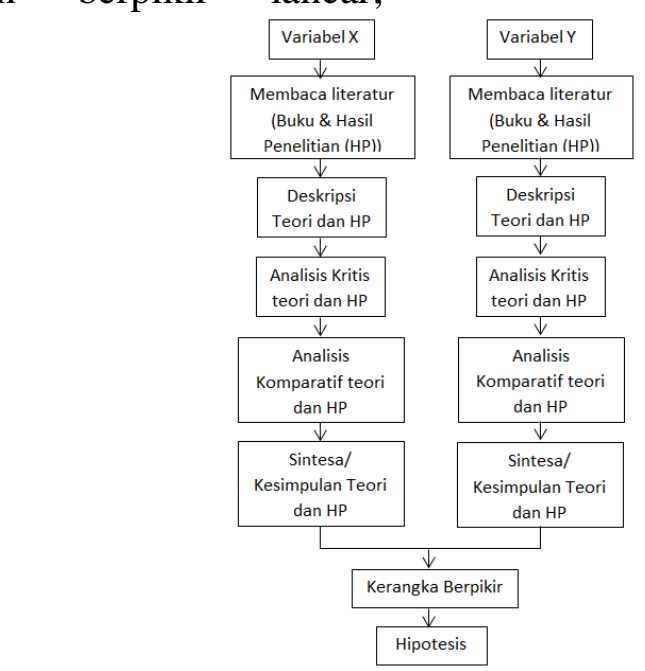

Gambar 1. Bagan alir studi literatur (diadaptasi dari Sugiyono, 2011)

Data penelitian diperoleh dari hasil penelitian oleh peneliti sendiri yang mengkaji tentang pemahaman konsep dan kemampuan berpikir kreatif pada pembelajaran fisika serta penelitianpenelitian lainnya yang relevan. Subjek dari data penelitian sebelumnya adalah siswa kelas X IPA 2 SMAN 4 Jember sebanyak 34 siswa. Penelitian tersebut dilakukan pada semester genap Tahun 2015. Teknik analisa data yang digunakan dalam penelitian ini adalah menggunakan analisis regresi linier untuk melihat hubungan kausal antara pemahaman kemampuan berpikir fleksibel; kemampuan berpikir orisinal; dan kemampuan elaborasi. Kao dkk. (2008) menjelaskan hubungan antara pemahaman konsep dengan konsep berpikir kreatif. Pemahaman konsep dapat menjadi stimulus untuk perkembangan potensi kreatif seseorang. Berdasarkan konsep hubungan antara pemahaman konsep dan berpikir kreatif, keduanya memiliki peran saling menguatkan, sehingga dapat dikatakan bahwa pemahaman konsep berbanding lurus dengan kemampuan berpikir kreatif.

\section{METODE}

Penelitian ini merupakan penelitian studi literatur menggunakan data teori yang ada dan penelitian sebelumnya sebagai acuan kajian seperti pada Gambar1. konsep dan kemampuan berpikir kreatif. Hasil kajian berupa analisis deskriptif terhadap hubungan kausal antara pemahaman konsep dan kemampuan berpikir kreatif berdasarkan $n$-gain pada masing-masing indikator pemahaman konsep dan kemampuan berpikir kreatif.

Hubungan kausal antara pemahaman konsep dan kemampuan berpikir kreatif dikaji pada tiap indikator. Penelitian ini mengkaji tentang keterkaitan antar indikator pada masing-masing variabel (pemahaman konsep dan kemampuan berpikir kreatif) secara deskriptif. 
Jurnal Pendidikan Fisika dan Keilmuan (JPFK) Vol 3 No 1 Maret 2017, hal 1-12

Avaliable online at : http://e-journal.unipma.ac.id/index.php/JPFK

Print ISSN: 2442-8868, Online ISSN: 2442-904X

\section{HASIL DAN PEMBAHASAN}

\section{Tinjauan Umum Hubungan Kausalitas Pemahaman Konsep dan Kemampuan Berpikir Kreatif}

Berdasarkan penelitian yang telah dilakukan tentang peningkatan pemahaman konsep dan kemampuan berpikir kreatif dengan menggunakan pendekatan konsep, terlihat bahwa meningkatnya pemahaman konsep siswa diikuti juga dengan peningkatan kemampuan berpikir kreatifnya. Kedua variabel memiliki proporsi yang saling menguatkan satu sama lain. Berikut grafik peningkatan pemahaman konsep dan kemampuan berpikir kreatif menggunakan pendekatan konsep pada pembelajaran fisika (pada Gambar 2 dan 3).

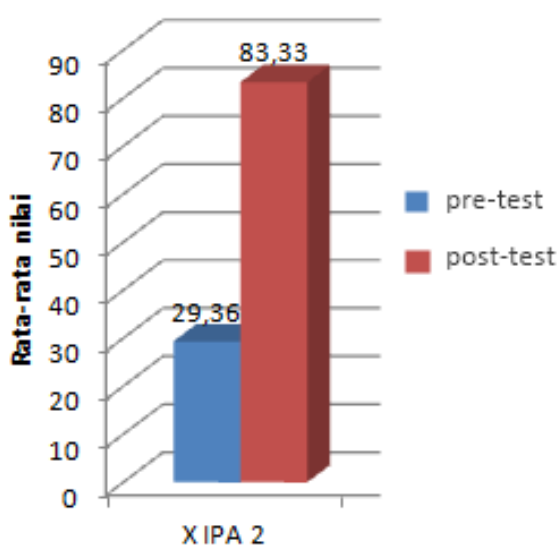

Gambar 2. Grafik Peningkatan Pemahaman Konsep (sumber: Trianggono, 2015)

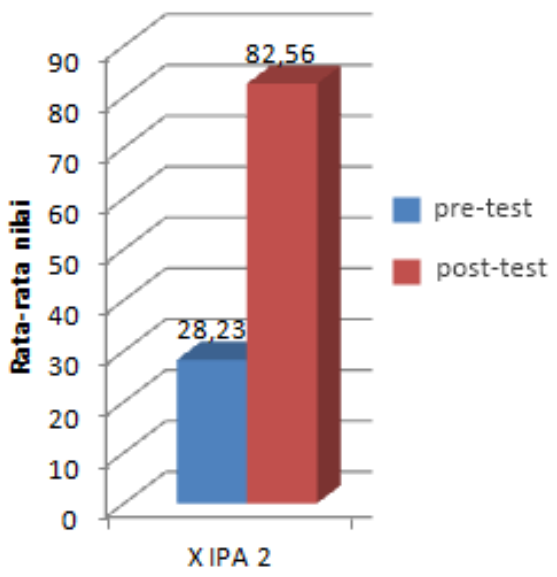

Gambar 3. Grafik Peningkatan Kemampuan Berpikir Kreatif (sumber: Trianggono, 2015)

Gambar 2 menunjukkan peningkatan pemahaman konsep siswa melalui pendekatan konsep dengan besar peningkatan (n-gain) sebesar 0,76. Gambar 3 menunjukkan peningkatan kemampuan berpikir kreatif siswa melalui pendekatan konsep dengan besar peningkatan (n-gain) sebesar 0,76. Berdasarkan data tersebut dapat dilihat besar peningkatan antara pemahaman konsep dan kemampuan berpikir kreatif memiliki pola peningkatan yang sama. Pola peningkatan yang sama antara kedua variabel pada kelas uji mengindikasikan bahwa terdapat hubungan kausalitas antara pemahaman konsep dan kemampuan berpikir kreatif.

Data peningkatan nilai pemahaman konsep dan kemampuan berpikir kreatif selanjutnya dianalisis menggunakan regresi linier sederhana untuk melihat besar hubungan kausalitas antara pemahaman konsep dan kemampuan berpikir kreatif. Berdasarkan hasil analisis, terlihat bahwa nilai koefisien 
Jurnal Pendidikan Fisika dan Keilmuan (JPFK) Vol 3 No 1 Maret 2017, hal 1-12

Avaliable online at : http://e-journal.unipma.ac.id/index.php/JPFK

Print ISSN: 2442-8868, Online ISSN: 2442-904X

determinasinya $\left(\mathrm{R}^{2}\right)$ sekitar 0,6743 . Hal ini berarti bahwa kontribusi pemahaman konsep terhadap kemampuan berpikir kreatif adalah sebesar $67,43 \%$ dan sisanya dipengaruhi oleh faktor lain. Berdasarkan uji parsial yang dilakukan terlihat bahwa nilai koefisien menunjukkan nilai 0,8932 . Hal ini berarti setiap 1 satuan peningkatan pemahaman konsep mempengaruhi peningkatan kemampuan berpikir kreatif sebesar 0,8932 satuan.

Hasil analisis data yang telah dijelaskan di atas memperlihatkan bahwa pemahaman konsep memiliki hubungan kausalitas yang signifikan dengan kemampuan berpikir kreatif.
Kajian lebih mendalam terletak pada hubungan antar indikator pada masing-masing variabel. Berikut akan dijabarkan tentang hubungan indikator pemahaman konsep dengan kemampuan berpikir kreatif.

Hubungan Indikator Pemahaman Konsep dengan Kemampuan Berpikir Kreatif

Masing-masing indikator pemahaman konsep memiliki proporsi kausalitas terhadap indikator kemampuan berpikir kreatif. Berikut akan diberikan grafik peningkatan masingmasing indikator pada pemahaman konsep dan kemampuan berpikir kreatif (pada Gambar 4 dan Gambar 5).

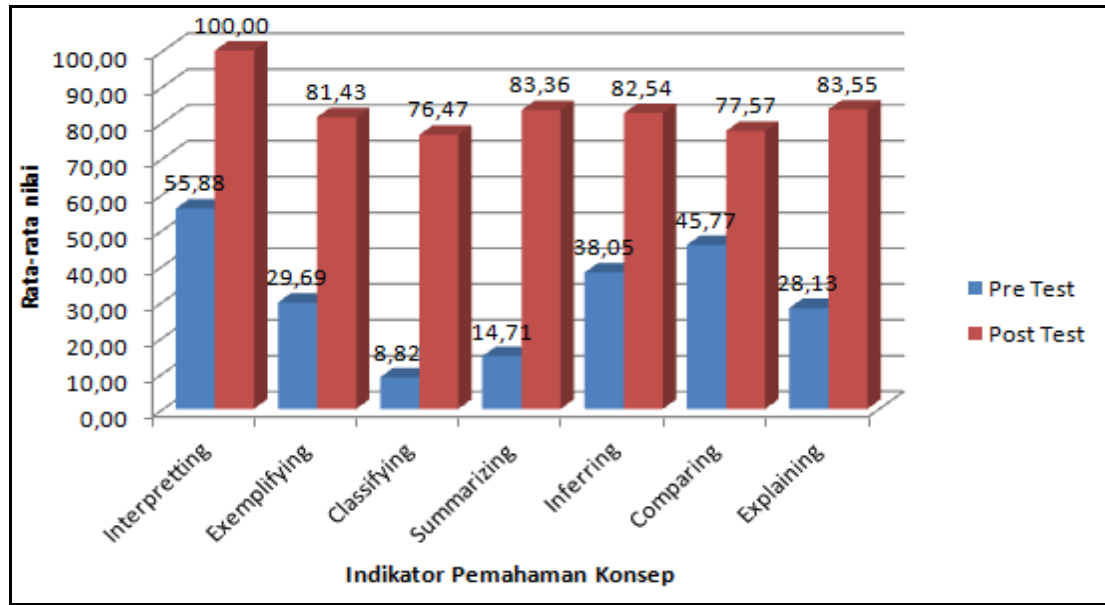

Gambar 4. Grafik Peningkatan Indikator Pemahaman Konsep (sumber: Trianggono, 2015)

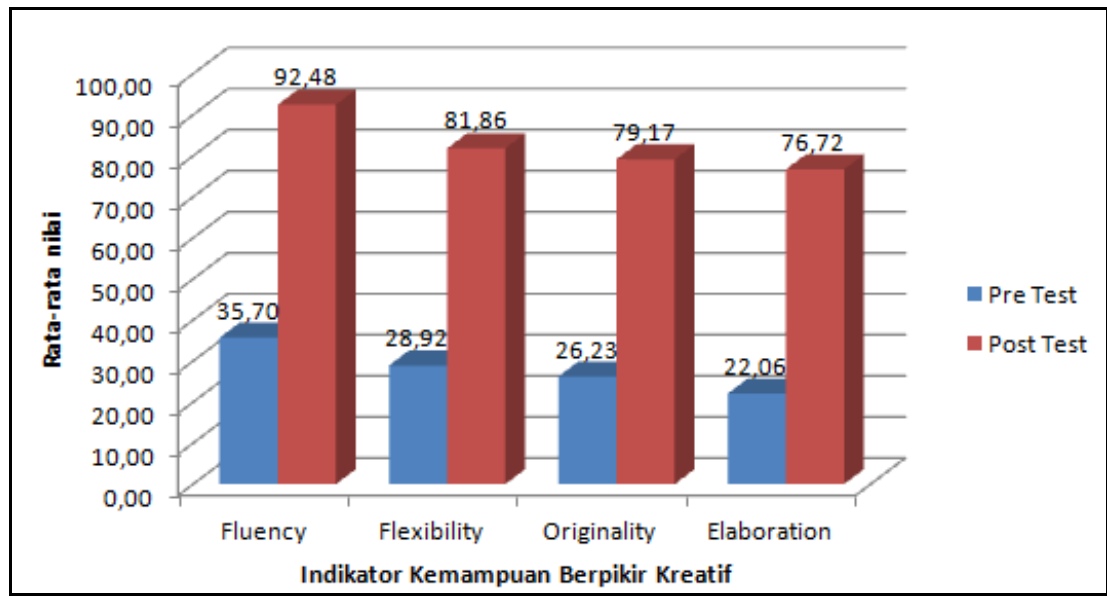

Gambar 5. Grafik Peningkatan Indikator Kemampuan Berpikir Kreatif (sumber: Trianggono, 2015)

Gambar 4 menjelaskan tentang grafik peningkatan indikator pemahaman konsep. Besar peningkatan dinyatakan dengan $n$-gain sebesar $\quad 1,00 \quad$ (interpretting); $\quad 0,74$ (exemplifying); $\quad 0,74 \quad$ (classifying); $\quad 0,80$ (summarizing); $\quad 0,72 \quad$ (inferring); $\quad 0,59$ (comparing); dan 0,77 (explaining). Gambar 5 menjelaskan tentang grafik peningkatan indikator kemampuan berpikir kreatif. Besar peningkatan secara berturut-urut; fluency $(0,88)$; flexibility $(0,74)$; originality $(0,72)$; 
Jurnal Pendidikan Fisika dan Keilmuan (JPFK) Vol 3 No 1 Maret 2017, hal 1-12

Avaliable online at : http://e-journal.unipma.ac.id/index.php/JPFK

Print ISSN: 2442-8868, Online ISSN: 2442-904X

elaboration $(0,70)$. Besar peningkatan yang bernilai 1 atau semakin mendekati 1 mengindikasikan bahwa peningkatan yang terjadi semakin signifikan. Berdasarkan grafik dan data n-gain pada masing-masing indikator kedua variabel, terlihat bahwa pola peningkatan yang terjadi memiliki karakteristik yang sama. Hal ini mengindikasikan bahwa indikator pemahaman konsep dan kemampuan berpikir kreatif memiliki keterkaitan atau hubungan kausalitas yang saling menguatkan. Berikut akan dijabarkan proporsi masing-masing indikator pemahaman konsep dan kemampuan berpikir kreatif yang memiliki hubungan kausalitas.

\section{Kemampuan Interpretasi (Interpreting)}

Kemampuan interpretasi adalah kemampuan seseorang dalam mengubah informasi dari satu bentuk ke bentuk lainnya. Berdasarkan hasil analisis menggunakan regresi linier berganda (hubungan antara indikator kemampuan berpikir kreatif dengan kemampuan interpretasi), didapatkan tingkat keeratan hubungan indikator kemampuan berpikir kreatif terhadap kemampuan interpretasi bernilai 0,547. Hal ini berarti keterkaitan indikator kemampuan berpikir kreatif terhadap kemampuan interpretasi sebesar 54,7\%. Semakin besar nilai tingkat keterkaitan tersebut menunjukkan bahwa semakin kuat pula hubungan antar variabel yang diuji. Hasil berbeda terdapat pada koefisien determinasi yang bernilai 0,2992. Hal ini berarti hanya sekitar $29,92 \%$ saja kontribusi dari indikator kemampuan berpikir kreatif terhadap peningkatan kemampuan menginterpretasi, sisanya dipengaruhi oleh faktor lain.

Contoh dari kemampuan interpretasi adalah pada saat siswa melihat pelangi (informasi visual), kemudian siswa tersebut mendefinisikan pelangi dalam bentuk tulisan/ ucapan (informasi verbal). Kemampuan menginterpretasi suatu informasi sangat berkaitan dengan kelancaran (fluency) seseorang dan keaslian (originality) ide orang tersebut dalam mengolah informasi. Kemampuan interpretasi juga ditunjang dari kelenturan (flexibility) dalam menafsirkan bervariasi dari suatu informasi dan merincinya dalam detail-detail tertentu (elaboration). Seseorang yang memiliki kemampuan berpikir fleksibel yang baik dapat melihat suatu informasi dari sudut pandang yang berbeda- beda, sehingga akan menghasilkan luaran yang berbeda pula. Kemampuan interpretasi akan bergantung pada bagaimana cara seseorang memandang sesuatu.

\section{Kemampuan Memberi Contoh (Exemplifying)}

Exemplifying adalah kemampuan siswa memberikan contoh tentang konsep atau prinsip umum. Berdasarkan hasil analisis menggunakan regresi linier berganda (hubungan antara indikator kemampuan berpikir kreatif dengan kemampuan memberi contoh), didapatkan tingkat keeratan hubungan indikator kemampuan berpikir kreatif terhadap kemampuan memberi contoh bernilai 0,7728. Hal ini berarti keterkaitan indikator kemampuan berpikir kreatif terhadap kemampuan memberi contoh sebesar 77,28\%. Semakin besar nilai tingkat keterkaitan tersebut menunjukkan bahwa semakin kuat pula hubungan antar variabel yang diuji. Hasil sinergi terdapat pada koefisien determinasi yang bernilai 0,5972 . Hal ini berarti sekitar $59,72 \%$ kemampuan berpikir kreatif berkontribusi terhadap peningkatan kemampuan memberikan contoh.

Contoh dari kemampuan ini adalah pada saat siswa diberikan tugas untuk memberikan contoh penerapan Hukum III Newton, siswa tersebut akan memberikan beberapa contoh tentang Hukum III Newton seperti gaya aksi reaksi antara gesekan dengan benda yang didorong, dan lain sebagainya. Kemampuan memberi contoh sangat erat kaitannya dengan kelancaran seseorang dalam mengaitkan peristiwa sehari-hari yang berkaitan dengan konsep yang diberikan. Kelenturan seseorang dalam mendefinisikan konsep juga mendukung proses penggalian informasi yang terkait dengan konsep yang dipelajari. Seseorang akan selalu berusaha memberikan contoh yang autentik dari dirinya sendiri, sehingga akan berusaha berbeda dengan lainnya. Seseorang yang memiliki pemahaman konsep yang baik akan berusaha memberikan detail-detail khusus pada setiap contoh yang diberikan.
3. Kemampuan Mengklasifikasi (Classifying)

\section{6 | Trianggono, Analisis Kausalitas Pemahaman Konsep Dengan Kemampuan ...}




\section{Jurnal Pendidikan Fisika dan Keilmuan (JPFK) Vol 3 No 1 Maret 2017, hal 1-12 \\ Avaliable online at : http://e-journal.unipma.ac.id/index.php/JPFK \\ Print ISSN: 2442-8868, Online ISSN: 2442-904X}

Kemampuan mengklasifikasi adalah kemampuan seseorang dalam mengetahui bahwa sesuatu (contoh) termasuk dalam kategori tertentu (konsep/prinsip). Berdasarkan hasil analisis menggunakan regresi linier berganda (hubungan antara indikator kemampuan berpikir kreatif dengan kemampuan mengklasifikasi), didapatkan tingkat keeratan hubungan indikator kemampuan berpikir kreatif terhadap kemampuan mengklasifikasi bernilai 0,4923. Hal ini berarti keterkaitan indikator kemampuan berpikir kreatif terhadap kemampuan mengklasifikasi sebesar 49,23\%. Hasil berbeda terdapat pada koefisien determinasi yang bernilai 0,2423. Hal ini berarti hanya sekitar 24,23\% saja kontribusi dari indikator kemampuan berpikir kreatif terhadap peningkatan kemampuan mengklasifikasi, sisanya dipengaruhi oleh faktor lain.

Kelancaran sangat dibutuhkan seseorang dalam mengklasifikasikan dengan cepat contoh-contoh yang termasuk dalam kategori tertentu. Seseorang harus memiliki kemampuan merinci detail yang baik sehingga akan memudahkan orang tersebut mendefinisikan contoh-contoh tersebut dalam suatu kategori yang sama.

\section{Kemampuan Meringkas}

\section{(Summarizing)}

Kemampuan meringkas adalah kemampuan seseorang dalam mengemukakan satu kalimat yang merepresentasikan informasi yang diterima atau mengabstraksi sebuah tema. Berdasarkan hasil analisis menggunakan regresi linier berganda (hubungan antara indikator kemampuan berpikir kreatif dengan kemampuan meringkas), didapatkan tingkat keeratan hubungan indikator kemampuan berpikir kreatif terhadap kemampuan meringkas bernilai 0,7033. Hal ini berarti keterkaitan indikator kemampuan berpikir kreatif terhadap kemampuan meringkas sebesar 70,33\%. Semakin besar nilai tingkat keterkaitan tersebut menunjukkan bahwa semakin kuat pula hubungan antar variabel yang diuji. Hasil sinergi terdapat pada koefisien determinasi yang bernilai 0,4946. Hal ini berarti sekitar 49,46\% kemampuan berpikir kreatif berkontribusi terhadap peningkatan kemampuan meringkas.

Seseorang yang memiliki kelancaran yang baik dalam mengolah informasi akan mudah dalam membuat suatu ringkasan tentang suatu informasi tersebut. Kelenturan dalam memahami perubahan makna suatu informasi sangat diperlukan dalam pengolahan ringkasan, sehingga akan memudahkan dalam perumusan kesimpulan dari suatu informasi yang kompleks. Setiap orang memiliki kemampuan meringkas yang berbeda-beda tergantung dari sudut pandang penilaian orang tersebut terhadap suatu informasi. Semakin banyak rincian detail yang diberikan dalam suatu ringkasan, informasi yang dapat ditangkap dari ringkasan tersebut semakin banyak, sehingga kemampuan elaborasi sangat dibutuhkan dalam kemampuan meringkas.

\section{Kemampuan Menyimpulkan (Inferring)}

Kemampuan menyimpulkan adalah kemampuan seseorang dalam mengabstraksi sebuah konsep atau prinsip melalui proses menemukan pola dalam sejumlah contoh hingga menjadi suatu kesimpulan. Berdasarkan hasil analisis menggunakan regresi linier berganda (hubungan antara indikator kemampuan berpikir kreatif dengan kemampuan menyimpulkan), didapatkan tingkat keeratan hubungan indikator kemampuan berpikir kreatif terhadap kemampuan menyimpulkan bernilai 0,6509. Hal ini berarti keterkaitan indikator kemampuan berpikir kreatif terhadap kemampuan menyimpulkan sebesar 65,09\%. Semakin besar nilai tingkat keterkaitan tersebut menunjukkan bahwa semakin kuat pula hubungan antar variabel yang diuji. Hasil sinergi terdapat pada koefisien determinasi yang bernilai 0,4237 . Hal ini berarti sekitar $42,37 \%$ kemampuan berpikir kreatif berkontribusi terhadap peningkatan kemampuan menyimpulkan.

Pembuatan kesimpulan melibatkan proses berpikir yang mendalam, sehingga diperlukan kelancaran dalam mengaitkan antara satu konsep dengan konsep lainnya 
Jurnal Pendidikan Fisika dan Keilmuan (JPFK) Vol 3 No 1 Maret 2017, hal 1-12

Avaliable online at : http://e-journal.unipma.ac.id/index.php/JPFK

Print ISSN: 2442-8868, Online ISSN: 2442-904X

dan kelenturan dalam menemukan ide dalam perumusan kesimpulan. Kesimpulan seseorang dalam menilai sesuatu akan berbeda-beda, jadi dibutuhkan keaslian pemikiran dan cara pandang yang bervariasi dalam penyusunan kesimpulan. Kreativitas sangat dibutuhkan seseorang dalam membuat kesimpulan yang komprehensif dan representatif.

\section{Kemampuan Membandingkan (Comparing)}

Kemampuan membandingkan adalah kemampuan seseorang dalam mendeteksi persamaan dan perbedaan antara dua atau lebih objek, peristiwa, ide, masalah, atau situasi. Berdasarkan hasil analisis menggunakan regresi linier berganda (hubungan antara indikator kemampuan berpikir kreatif dengan kemampuan membandingkan), didapatkan tingkat keeratan hubungan indikator kemampuan berpikir kreatif terhadap kemampuan membandingkan bernilai 0,4027. Hal ini berarti keterkaitan indikator kemampuan berpikir kreatif terhadap kemampuan membandingkan sebesar 40,27\%. Semakin besar nilai tingkat keterkaitan tersebut menunjukkan bahwa semakin kuat pula hubungan antar variabel yang diuji. Hasil sinergi terdapat pada koefisien determinasi yang bernilai 0,1622 . Hal ini berarti sekitar $16,22 \%$ saja kontribusi kemampuan berpikir kreatif terhadap peningkatan kemampuan membandingkan.

Proses pendeteksian persamaan dan perbedaan antara dua objek atau lebih membutuhkan kejelian dan kelenturan perspektif pengamatan terhadap objek tersebut. Kemampuan membandingkan sangat erat kaitannya dengan pengamatan pada detail-detail khusus yang dimiliki oleh suatu objek, sehingga kemampuan elaborasi sangat dibutuhkan dalam proses membandingkan.

\section{Kemampuan Menjelaskan (Explaining)}

Kemampuan menjelaskan adalah kemampuan seseorang dalam membuat dan menggunakan model sebab akibat dalam sebuah sistem. Berdasarkan hasil analisis menggunakan regresi linier berganda (hubungan antara indikator kemampuan berpikir kreatif dengan kemampuan menjelaskan), didapatkan tingkat keeratan hubungan indikator kemampuan berpikir kreatif terhadap kemampuan menjelaskan bernilai 0,7156. Hal ini berarti keterkaitan indikator kemampuan berpikir kreatif terhadap kemampuan menjelaskan sebesar 71,56\%. Semakin besar nilai tingkat keterkaitan tersebut menunjukkan bahwa semakin kuat pula hubungan antar variabel yang diuji. Hasil sinergi terdapat pada koefisien determinasi yang bernilai 0,5122 . Hal ini berarti sekitar $51,22 \%$ kemampuan berpikir kreatif berkontribusi terhadap peningkatan kemampuan menjelaskan.

Seseorang yang lancar dalam membuat hubungan antara satu konsep dengan konsep lainnya akan memiliki kemampuan menjelaskan yang lebih baik dibandingkan dengan yang kurang lancar. Sebagai misal, siswa diminta untuk menjelaskan keterkaitan antara perubahan suhu dengan perubahan wujud zat. Siswa yang memiliki kelancaran dalam pengolahan informasi tentang konsep suhu dan perubahan wujud zat (mengaitkan konsep perubahan suhu dengan perubahan wujud zat) akan mudah dalam menjelaskan hubungan tersebut. Kemampuan menjelaskan seseorang akan lebih baik jika orang tersebut mampu memberikan rincian secara detail hubungan antar konsep tersebut.

Berdasarkan uraian di atas, dapat dilihat bahwa semua indikator pemahaman konsep dapat ditingkatkan juga dengan peningkatan indikator kemampuan berpikir kreatif. Indikator kemampuan berpikir kreatif memiliki peran positif dalam menunjang pemahaman konsep seseorang, artinya semakin baik kemampuan berpikir kreatif seseorang, maka pemahaman seseorang terhadap suatu konsep juga akan semakin baik. Masing-masing indikator kedua variabel memiliki keterkaitan yang konstruktif. Berikut akan dijabarkan kajian tentang hubungan indikator kemampuan berpikir kreatif dengan pemahaman konsep.

\section{8 | Trianggono, Analisis Kausalitas Pemahaman Konsep Dengan Kemampuan ...}


Jurnal Pendidikan Fisika dan Keilmuan (JPFK) Vol 3 No 1 Maret 2017, hal 1-12

Avaliable online at : http://e-journal.unipma.ac.id/index.php/JPFK

Print ISSN: 2442-8868, Online ISSN: 2442-904X

Hubungan Indikator Kemampuan Berpikir Kreatif dengan Pemahaman Konsep

\section{Kemampuan Berpikir Lancar/ Kelancaran (Fluency)}

Kemampuan berpikir lancar adalah kemampuan seseorang dalam mencetuskan banyak gagasan, jawaban, penyelesaian masalah yang relevan dalam waktu singkat (Munandar 2009; Kim, 2007). Kemampuan berpikir lancar juga dapat didefinisikan sebagai kemampuan seseorang dalam mengaitkan satu konsep dengan konsep dengan cepat dan tepat. Seseorang yang dapat mengaitkan satu konsep dengan konsep dengan cepat pasti sudah memiliki pemahaman yang baik tentang konsep yang sedang dikaji. Pemahaman konsep yang baik akan memudahkan seseorang dalam mengaitkan konsep tersebut dengan konsep lain dan peristiwa sehari-hari.

Berdasarkan hasil analisis menggunakan regresi linier berganda (hubungan antara indikator pemahaman konsep dengan kemampuan berpikir lancar), didapatkan tingkat keeratan hubungan indikator pemahaman konsep terhadap kemampuan berpikir lancar bernilai 0,9734 . Hal ini berarti keterkaitan indikator pemahaman konsep terhadap kemampuan berpikir lancar sebesar $97,34 \%$. Semakin besar nilai tingkat keterkaitan tersebut menunjukkan bahwa semakin kuat pula hubungan antar variabel yang diuji. Hasil sinergi terdapat pada koefisien determinasi yang bernilai 0,9474 . Hal ini berarti sekitar $94,74 \%$ pemahaman konsep berkontribusi terhadap peningkatan kemampuan berpikir lancar.

Sebagai contoh, siswa yang memiliki pemahaman konsep yang baik pada konsep kelistrikan akan lancar dalam menjelaskan kebakaran yang diakibatkan oleh hubungan pendek arus listrik. Siswa tersebut dapat menginterpretasikan peristiwa hubungan pendek arus listrik sebagai penyebab kebakaran. Siswa tersebut juga dapat menjelaskan proses terjadinya hubungan pendek arus listrik sampai terjadinya kebakaran tersebut. Kemampuan-kemampuan dalam pemahaman konsep tersebut dapat meningkatkan kelancaran seseorang dalam mencetuskan banyak gagasan, jawaban, dan penyelesaian masalah yang relevan dalam waktu singkat.

\section{Kemampuan Berpikir Fleksibel/ Kelenturan (Flexibility)}

Kemampuan berpikir fleksibel adalah kemampuan seseorang dalam menghasilkan gagasan, jawaban atau pertanyaan yang bervariasi, dapat melihat suatu masalah dari sudut pandang yang berbeda-beda, mencari banyak alternatif atau arah penyelesaian yang berbeda-beda serta mampu merubah cara pendekatan atau cara pemikiran (Munandar 2009, Kim 2007). Berdasarkan hasil analisis menggunakan regresi linier berganda (hubungan antara indikator pemahaman konsep dengan kemampuan berpikir fleksibel), didapatkan tingkat keeratan hubungan indikator pemahaman konsep terhadap kemampuan berpikir fleksibel bernilai 0,9717. Hal ini berarti keterkaitan indikator pemahaman konsep terhadap kemampuan berpikir fleksibel sebesar 97,17 \%. Semakin besar nilai tingkat keterkaitan tersebut menunjukkan bahwa semakin kuat pula hubungan antar variabel yang diuji. Hasil sinergi terdapat pada koefisien determinasi yang bernilai 0,9441 . Hal ini berarti sekitar 94,41 \% pemahaman konsep berkontribusi terhadap peningkatan kemampuan berpikir fleksibel.

Seseorang yang memiliki pemahaman konsep yang baik akan mampu menghasilkan gagasan yang bervariasi. Pemahaman yang tinggi terhadap suatu konsep menstimulus otak untuk selalu mengembangkan gagasan tentang konsep tersebut, sehingga akan memunculkan gagasan yang bervariasi. Kemampuan interpretasi yang baik akan memunculkan pandangan terhadap suatu konsep dari sudut pandang yang berbedabeda. Sebagai contoh, pembalap mobil yang memiliki pemahaman yang baik tentang konsep percepatan sentripetal dan percepatan sentrifugal akan memiliki banyak ide yang bervariasi dalam menentukan waktu dan kecepatan saat 
Jurnal Pendidikan Fisika dan Keilmuan (JPFK) Vol 3 No 1 Maret 2017, hal 1-12

Avaliable online at : http://e-journal.unipma.ac.id/index.php/JPFK

Print ISSN: 2442-8868, Online ISSN: 2442-904X

menyalip dalam keadaan menikung. Berdasarkan uraian tersebut, dapat dikatakan bahwa pemahaman yang baik terhadap suatu konsep akan menstimulus otak untuk berpikir secara fleksibel menghasilkan gagasan-gagasan yang bervariasi dari sudut pandang yang berbeda-beda.

\section{Kemampuan Berpikir Orisinal (Originality)}

Kemampuan berpikir orisinal adalah kemampuan seseorang dalam melahirkan gagasan yang baru dan unik (jarang diungkapkan orang), memikirkan cara yang tidak lazim untuk mengungkapkan diri serta mampu membuat kombinasikombinasi yang tidak lazim dari bagianbagian atau unsur-unsur tertentu (Munandar 2009; Kim, 2007). Berdasarkan hasil analisis menggunakan regresi linier berganda (hubungan antara indikator pemahaman konsep dengan kemampuan berpikir orisinal), didapatkan tingkat keeratan hubungan indikator pemahaman konsep terhadap kemampuan berpikir orisinal bernilai 0,9532. Hal ini berarti keterkaitan indikator pemahaman konsep terhadap kemampuan berpikir orisinal sebesar 95,32\%. Semakin besar nilai tingkat keterkaitan tersebut menunjukkan bahwa semakin kuat pula hubungan antar variabel yang diuji. Hasil sinergi terdapat pada koefisien determinasi yang bernilai 0,9086 . Hal ini berarti sekitar 90,86 \% pemahaman konsep berkontribusi terhadap peningkatan kemampuan berpikir orisinal.

Penilaian terhadap kemampuan berpikir orisinal ini sebenarnya sulit dilakukan karena harus membandingkan hasil berpikir seseorang dengan orang lain. Pada dasarnya berpikir orisinal adalah tingkatan kemampuan berpikir yang lebih tinggi dibandingkan kemampuan berpikir fleksibel. Seseorang tidak hanya memberikan gagasan yang bervariasi, tetapi juga harus benar-benar autentik berasal dari hasil berpikirnya. Kemampuan berpikir orisinal sudah tentu didasari dari pemahaman konsep yang kuat dan kemampuan evaluasi yang baik. Pemahaman yang baik terhadap suatu konsep menjadi dasar pemikiran seseorang dalam membuat gagasan yang berkaitan dengan konsep tersebut.

Kemampuan evaluasi digunakan untuk menyeleksi dugaan ide yang sangat berbeda dengan hasil berpikir orang lain. Sebagai contoh, seorang mahasiswa memiliki pemahaman konsep yang baik tentang perubahan energi dan pemanfaatan energi, mahasiswa tersebut berpikir bahwa tumbuhan merupakan sumber energi yang melimpah, sehingga mahasiswa tersebut memiliki gagasan untuk membuat suatu penelitian tentang pemanfaatan tumbuhan sebagai penghasil listrik. Pemahaman konsep yang baik terhadap perubahan dan pemanfaatan energi menjadi dasar siswa tersebut dalam memunculkan gagasan yang autentik dan belum pernah dicetuskan oleh orang lain. Gagasan tersebut dikatakan orisinal/ autentik karena gagasan tersebut belum pernah dipublikasikan/ dicetuskan oleh orang lain. Berdasarkan uraian tersebut dapat dikatakan bahwa pemahaman konsep menjadi dasar seseorang dalam memunculkan gagasan autentik terhadap konsep tersebut.

\section{Kemampuan Elaborasi (Elaboration)}

Kemampuan mengelaborasi adalah kemampuan seseorang dalam memperkaya dan mengembangkan suatu gagasan atau produk, menambahkan atau memerinci detail-detail dari suatu obyek, gagasan atau situasi sehingga lebih menarik (Munandar, 2009; Kim, 2007). Berdasarkan hasil analisis menggunakan regresi linier berganda (hubungan antara indikator pemahaman konsep dengan kemampuan berpikir elaborasi), didapatkan tingkat keeratan hubungan indikator pemahaman konsep terhadap kemampuan berpikir elaborasi bernilai 0,9533. Hal ini berarti keterkaitan indikator pemahaman konsep terhadap kemampuan berpikir elaborasi sebesar 95,33 $\%$. Semakin besar nilai tingkat keterkaitan tersebut menunjukkan bahwa semakin kuat pula hubungan antar variabel yang diuji. Hasil sinergi terdapat pada koefisien determinasi yang bernilai 0,9087 . Hal ini berarti sekitar

\section{0 | Trianggono, Analisis Kausalitas Pemahaman Konsep Dengan Kemampuan ...}


Jurnal Pendidikan Fisika dan Keilmuan (JPFK) Vol 3 No 1 Maret 2017, hal 1-12

Avaliable online at : http://e-journal.unipma.ac.id/index.php/JPFK Print ISSN: 2442-8868, Online ISSN: 2442-904X

90,87\% pemahaman konsep berkontribusi terhadap peningkatan kemampuan berpikir elaborasi.

Kemampuan elaborasi berkaitan dengan penambahan rincian secara detail terhadap suatu gagasan. Kemampuan memberikan rincian secara detail ini didasari oleh pemahaman konsep yang kuat terhadap objek atau gagasan yang sedang dikaji. Seseorang yang memiliki kemampuan elaborasi yang baik sudah pasti memiliki pemahaman yang baik tentang apa yang dikaji. Sebagai contoh, siswa diminta untuk menjelaskan penggunaan air conditioner mobil pada saat hujan. Siswa yang memiliki pemahaman konsep yang baik tentang perpindahan kalor dan perubahan wujud zat akan memberikan penjelasan yang jelas dan terinci tentang peristiwa tersebut. Siswa dengan pemahaman konsep yang baik akan memberikan penjelasan tentang perpindahan kalor yang terjadi karena perbedaan suhu permukaan luar dan dalam kaca mobil yang mengakibatkan perubahan wujud zat berupa embun yang akan menempel di kaca dan mengganggu penglihatan pengendara secara terperinci. Siswa tersebut juga akan memberikan contoh-contoh lain yang berkaitan dengan peristiwa yang sedang dikaji. Berdasarkan uraian tersebut dapat dikatakan bahwa kemampuan memberikan rincian secara detail sangat bergantung pada pemahaman terhadap konsep yang sedang dikaji.

Berdasarkan nilai tingkat keterkaitan antar indikator, dapat disimpulkan bahwa pemahaman konsep memiliki kontribusi yang sangat tinggi dan signifikan $(\mathrm{R}>$ $90 \%$ dan $\mathrm{R}^{2}>90 \%$ ) terhadap peningkatan kemampuan berpikir kreatif, sedangkan kemampuan berpikir kreatif memiliki kontribusi yang cukup $(40 \%<\mathrm{R}<77 \%$ dan $\left.16 \%<\mathrm{R}^{2}<59 \%\right)$ terhadap peningkatan pemahaman konsep.

Pemahaman konsep dan kemampuan berpikir kreatif memiliki hubungan kausalitas yang bersifat konstruktif. Berdasarkan uraian tentang hubungan antar indikator pemahaman konsep dan kemampuan berpikir kreatif, dapat terlihat bahwa keduanya memiliki peran yang saling menguatkan dalam pemecahan masalah fisika. Hubungan kausalitas antara pemahaman konsep dan kemampuan berpikir kreatif dapat digambarkan dalam sebuah skema berpikir pada Gambar 6 .

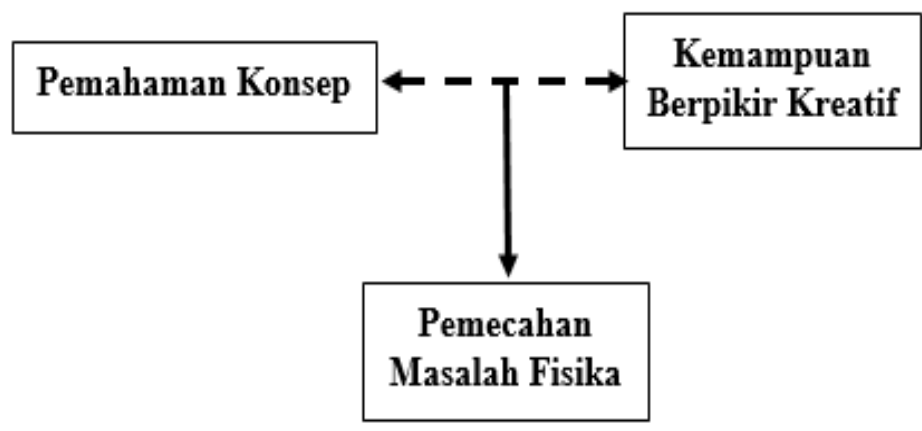

Gambar 6. Skema Berpikir Hubungan Kausalitas Pemahaman Konsep dengan Kemampuan Berpikir Kreatif dalam Pemecahan Masalah Fisika

Permasalahan fisika yang kompleks dapat diselesaikan dengan pemahaman konsep dan kemampuan berpikir kreatif yang baik. Pemahaman konsep menjadi dasar seseorang dalam membuat penyelesaian masalah fisika, sedangkan kemampuan berpikir kreatif menjadi sistematika berpikir seseorang dalam memperoleh gagasan komprehensif dalam penyelesaian masalah fisika.

\section{KESIMPULAN}

Pemahaman konsep dan kemampuan berpikir kreatif memiliki hubungan kausalitas yang bersifat konstruktif yang saling menguatkan peran masing-masing 
Jurnal Pendidikan Fisika dan Keilmuan (JPFK) Vol 3 No 1 Maret 2017, hal 1-12

Avaliable online at : http://e-journal.unipma.ac.id/index.php/JPFK

Print ISSN: 2442-8868, Online ISSN: 2442-904X

dalam penyelesaian masalah fisika. Hal tersebut terlihat dari besar kontribusi dari masing-masing variabel dengan nilai determinasi $>50 \%$ yang menggambarkan bahwa keterkaitan antara kedua variabel dapat dikatakan saling menguatkan satu sama lain. Keterkaitan yang kuat juga terlihat pada hubungan antara indikator pemahaman konsep dan kemampuan berpikir kreatif yang menunjukkan nilai tingkat keeratan hubungan yang cukup tinggi (>90\%). Pemahaman konsep menjadi dasar seseorang untuk memahami permasalahan fisika dan membuat hubungan-hubungan antar konsep dalam penyelesaian masalah fisika. Kemampuan berpikir kreatif berperan dalam sistematika berpikir seseorang dalam memunculkan gagasan yang bervariasi, autentik, dan terperinci dalam suatu penyelesaian masalah fisika. Pemecahan masalah fisika membutuhkan pemikiran yang komprehensif antara pemahaman konsep yang baik dan kemampuan berpikir kreatif yang tinggi.

\section{DAFTAR PUSTAKA}

Arends, R. I. (2012). Learning to Teach: Ninth Edition. USA: The McGrawHill Companies

Ennis, R. H. (1995). Critical Thinking. Illionis: Prentice Hall

Guilford, J. P. (1967). The Nature of Human Intelligence. New York: McGraw-Hill

Johnson, S. (2010). Where Good Ideas Come From. New York: Riverhead books

Kao, G. Y.-M., Lin, S. S. J., \& Sun, C.-T. (2008). Breaking Concept Boundaries to Enhance Creative Potential: Using Integrated Concept Maps for Conceptual SelfAwareness. Elsevier: Computer \& Education 51, 1718-1728
Kim, K. (2007). The Two Torrance Creativity Test: The Torrance Test of Creative Thinking and Thinking Creatively in Action and Movement. In Ai-Girl Tan (Ed). Creativity $A$ Handbook for Teacher, 117-141. Singapore: World Scientific Publishing Co. Pte. Ltd

Krathwohl, D. R. \& Anderson, L. W. (2001). A Taxonomy for Learning, Teaching, and Assessing: A Revision of Bloom's Taxonomy of Educational Obejctives. New York: Longman

McGregor, D. (2007). Thinking; Developing Learning. A Guide to Thinking Skills in Education. McGrawHill: Open University Press

Munandar, Utami (2009). Pengembangan Kreativitas Anak Berbakat. Jakarta: Rineka Cipta

Sugiyono. (2011). Metode Penelitian Kuantitatif Kualitatif dan $R \& D$. Bandung: Alfabeta

Susanto, H. A. (2011). Pemahaman Pemecahan Masalah Pembuktian Sebagai Sarana Berpikir Kreatif. Prosiding Seminar Nasional Penelitian, Pendidikan, dan Penerapan MIPA, Fakultas MIPA, Universitas Negeri Yogyakarta, 189196. Yogyakarta: Universitas Negeri Yogyakarta

Trianggono, M. M. (2015). Pengembangan Perangkat Pembelajaran Fisika Berbasis Pendekatan Konsep untuk Meningkatkan Hasil Belajar Siswa SMA. (Tesis, Universitas Negeri Surabaya)

Wulandari, Anis Elyana. (2016). Hubungan Kemampuan Berpikir Kreatif dan Pemahaman Konsep terhadap Kemampuan Pemecahan Masalah Matematika. Jurnal Ekuivalen Vol 24 No. 2 